\title{
Obama, Romney, and Christian Realism
}

\section{R. Ward Holder • Peter B. Josephson}

Published online: 21 August 2012

(C) Springer Science+Business Media, LLC 2012

One unremarked but essential theme of the 2012 presidential campaign is the unfolding debate surrounding religion (especially Christianity) and its role in shaping government policy. On the one hand, the Republican Party candidate Mitt Romney stakes a claim to promote a "Christian" political economy, and the leading Republican budget negotiator Congressman Paul Ryan does as well. This claim may be categorized broadly as a "prosperity gospel" claim. ${ }^{1}$ On the other hand, Barack Obama has worked to ground his own approach to political economy on an alternative Christian foundation, one that may be characterized broadly as a "social gospel" claim. ${ }^{2}$ In short, the 2012 election may serve as a referendum on the demands of the Christian faith in reconstructing the American political economy.

In 2012 the United States faces such economic and international challenges that many citizens fear the nation is approaching a decline and fall. In the words of one scholar, America needs a Christian politics "fit for an age of anxiety."3

\footnotetext{
${ }^{1}$ Ryan contends that he developed his budget plan (which Mitt Romney endorsed) "using my Catholic faith"-an understanding the United States Council of Catholic Bishops quickly disputed. Dana Milbank, "A Faith-based Budget Lesson for Paul Ryan," Chicago Tribune, May 1, 2012. http://articles.chicagotribune.com/2012-05-01/ news/ct-oped-0501-bishops-20120501 1 ryan-s-budget-paul-ryanhouse-republican-budget Accessed May 29, 2012.

${ }^{2}$ In April 2009 Obama described the stimulus package in phrases explicitly drawn from social gospel teachings. Obama's "new foundation" for economic policy is the Sermon on the Mount. Barack Obama, "Obama, Barack". "The New Foundation," April 14, 2009. http://www.whitehouse.gov/the-press-office/remarks-presidenteconomy-georgetown-university Accessed July 31, 2011

${ }^{3}$ John Patrick Diggins, Why Niebuhr Now? (Chicago: University of Chicago Press, 2011), 13
}

R. W. Holder $(\square)$

Saint Anselm College,

100 St. Anselm Drive, Box 1762, Manchester, New Hampshire 03102, USA

e-mail: wholder@anselm.edu

P. B. Josephson

Saint Anselm College,

100 St. Anselm Drive, Box 1680, Manchester, New Hampshire 03102, USA
That Christian politics is best developed by Reinhold Niebuhr. Niebuhr, the most profound American guide to the problem of Christian statecraft, offers us two kinds of theory about political economy. The first is a normative theory of a prophetic Christian call for justice. The second is a realistic and cautionary account of the ways that sin, economic selfinterest, and political power work together to frustrate the "children of light" who seek either laissez-faire or socialscientific utopias. The Niebuhrian paradox is that the distance between Christian theory and political practice can never be breached, and yet Christians are called to attempt to live justly in the political and economic worlds. A Niebuhrian analysis demonstrates that while both Romney and Obama stake claims to seek a Christian political economy, each fails to grasp one of the two truths that Niebuhr articulates. Romney rejects the Christian prophetic call to economic justice, and denies that unfettered capitalism presents problems of the just distribution and exercise of power. Obama accepts the Christian call to economic justice, but too often ignores the ways that pride and economic self-interest corrupt even the best intended attempts at social salvation. And the American public, whether Christian or secular, Occupier or Tea Partier, has no patience for such subtleties. Realism, especially Christian realism, holds too little sway in public debate.

\section{Reinhold Niebuhr and Political Economy}

Reinhold Niebuhr's ministry came to maturity in Detroit, during the years when Henry Ford was revolutionizing both the automobile industry and American business models. Simultaneously, the Social Gospel movement achieved its greatest prominence. The social gospel movement was the leading progressive movement in American Protestantism in the early $20^{\text {th }}$ century. The movement's leaders aimed to apply the lessons of the Christian gospel to the larger problems of society to accomplish social salvation. In this manner they maintained that Christians could forward the establishment of the kingdom of God on earth. Niebuhr 
developed his early considerations of political economy in the context of a debate between the needs of American industry and the demands of Christian social concern.

Niebuhr recalled for his readers that the Christian gospel demanded care for the downtrodden. In this, he acted as a prophet - the nation of Israel had been called to give aid to the widow and the orphan (Isaiah 1.17), and America should likewise aid those who were most vulnerable and oppressed by the society and its systems. But instead, America had accepted systems that enshrined the ownership of property and the ethical problems that accompanied such idolatry. ${ }^{4}$

Further, Niebuhr warned about the ways in which selfinterested communities would bend political power and even rationality to their own economic benefit. The free market is not moved by motivations of justice, but by motives of profit. The actors do not seek to do right, but to serve their own interests. ${ }^{5}$ Niebuhr wrote, "Economic desires are never merely the expression of the hunger or the survival impulse in human life. The desires for 'power and glory' are subtly compounded with the more primeval impulse. $" 6$ Indeed, Niebuhr reminds us that when a market interest claims to work for the public good, it is masking its own private interests. (Perhaps it masks that interest even from itself.) In Niebuhr's account, economic interests would inevitably seek to bend the goods of the political realm to their own ends. ${ }^{7}$

Moreover, on Niebuhr's terms the free market may actually produce injustices. Niebuhr wrote that "in modern society the basic mechanisms of justice are becoming more and more economic rather than political, in the sense that economic power is the most basic power." ${ }^{8}$ For Niebuhr, economic power is still power, and the centralization of economic power is as much a danger to justice as the centralization of political power. He wrote, "With the increased centralisation of economic power in the period of

\footnotetext{
${ }^{4}$ Reinhold Niebuhr, "Property and the Ethical Life," The World Tomorrow 14 (1931): 191.

${ }^{5}$ Reinhold Niebuhr, The Irony of American History, With a new Introduction by Andrew J. Bacevich (Chicago: University of Chicago Press, 2008), 96. The Children of Light and the Children of Darkness: $A$ Vindication of Democracy and a Critique of its Traditional Defense (New York: Charles Scribner's Sons, 1944), 20, 30. In this the bourgeois-liberal misses the deeper motives of human behaviormotives that were quite clear to founders like James Madison. Irony, 94, 96.

${ }^{6}$ Children, 61.

${ }^{7}$ Irony, 95 . The modern economic term is rent-seeking, defined as “... the use of the political process to procure special privileges, including regulations that harm one's competitors. Lobbying for protectionism is a classic example as is harassing one's more successful competitors with antitrust lawsuits." See Wall Street Journal editorial, "Rent Seekers Attack Microsoft," November 15, 1999. http://0-search.proquest.com.library.anselm.edu/wallstreetjournal/docview/398710132/ 1370577031461E1A1C6/6? accountid=13640 accessed May 30, 2012.

${ }^{8}$ Reinhold Niebuhr, An Interpretation of Christian Ethics (New York: Harper and Brothers Publishers, 1935), 183.
}

modern industrialism, this development merely means that society as such does not control economic power as much as social well-being requires; and that the economic, rather than the political and military, power has become the significant coercive force of modern society." bank that is too big to fail represents not only a problem of political economy, but an ethical threat as well. Economic power is at its foundation private, and on Niebuhr's terms is "irresponsible" to society. ${ }^{10}$ The claim that the free market imposes no injustice because all transactions are consensual misses the realities of the distribution and exercise of economic power. "The interests of individuals are, in other words, never exactly identical with those of their communities." $" 11$

In spite of this critique, Niebuhr came to reject the Social Gospel alternative to laissez-faire capitalism. The movement's hope for the salvation of the community, Niebuhr believed, was a false hope. While individuals are capable of moral and even agapic acts of love, political communitiesfacing greater necessities, bound together by an almost tribal mythos, and dependent upon force for social cohesion, are not. ${ }^{12}$ The demands of love and the requirements of political justice impose what Niebuhr called "the double focus of the moral life." $" 13$ Of greatest concern for Niebuhr is "the final peril of combining political and economic power," a combination that could be accomplished either by co-option of the free market by "bureaucratic-political" decision-making, or the co-option of the political process by industry.

For Niebuhr, then, the modern world was presented with two interlocking problems. The first problem was that of modern economics - modern humanity had transformed the will-to-live into the will-to-power (thus allowing unfettered accumulation of wealth under the guise of protection of life), had allowed the right of private property to become an absolute principle of societal life, and had countenanced the deliverance of political power to the altar of economic power. The second was the problem of the poor. Niebuhr saw that a systemic and political approach was necessaryand provided a moral critique of merely private and charitable attempts to address the problem. ${ }^{14}$ But Niebuhr also counseled against the prideful claims of social utopians, and offered chastened expectations for what government might accomplish. On the one hand he favored developing public governmental power as a check on a private economic power, and on the other he warned that the bureaucratic attachment to regulation would produce injustices of its own.

\footnotetext{
$\overline{{ }^{9} \text { Moral, 14-15. }}$

${ }^{10}$ Moral, 14-15; Christian Ethics, 183.

${ }^{11}$ Moral, 274-5; Irony, 94-5. Children 115, 117-118.

${ }^{12}$ Moral 3, 5-9, 257, 266-267.

${ }^{13}$ Moral, 257, 267.

${ }^{14}$ Irony, 104, 126.
} 


\section{Sins of the Laissez-Faire Industrialist}

Niebuhr's account of the history of western civilization, from the ancient Greeks to the Christians to the moderns, treats modernity and especially bourgeois modernity as a rebellion against the Christian view. The bourgeois modern Enlightenment claimed that society could be made to behave rationally even though the actors themselves were motivated primarily by their own interests. In the work of Adam Smith, an invisible hand guides free agents to accomplish cooperation and even social harmony. That teaching has contributed to the ideology of the prosperity gospel - a teaching that the pursuit of worldly profit is God's plan for us. Disciples of Smith believe they have found a mechanism that can manage society justly without coercion, through a system of natural liberty. ${ }^{15}$ Mitt Romney is clearly one of these disciples. His opposition to regulation and his belief in the power of the free market to establish just ends through just means are clear examples of this.

Romney has argued that his candidacy for the presidency should be based on his economic prowess - that as America faces its most significant economic crisis since the Great Depression, his business acumen provides him with greater qualifications than Barack Obama. Belying the stereotype of Romney as a figure who simply doesn't understand the individual and family pain of the disruptions of lost jobs, he has written about his experience with the unemployed. He noted, "Trade is good for the nation and for the average citizen, but it is decidedly not good for everybody." experiences in counseling those who had lost jobs in his role as a Mormon lay pastor, Romney remarked that for his congregants, this was a "...deeply traumatic personal experience" ${ }^{, 17}$ with deep and troubling consequences. Romney has seen the devastating consequences of economic woe.

Yet Romney does not draw a lesson of economic justice from this experience. For Romney, economics is a field of unfettered liberty. America is only great in that it has allowed innovations and harnessed the power of human desires - free enterprise has met real human needs. This has required risk, and that risk has not been equally shared, so of course, the rewards have also been unequally distributed. Thus, Romney rejects the idea that Christianity requires a response toward the disadvantaged by the society. This provides a context for his comment that he "...isn't concerned about the very poor." ${ }^{, 18} \mathrm{He}$ sees some need for

\footnotetext{
${ }^{15}$ Irony, 33, 92. In The Children of Light, 24-26, Niebuhr is careful to distinguish Smith's actual teaching, which included a moral center, from the popularized corruption of his teaching.

${ }^{16}$ Mitt Romney, No Apology: Believe in America (New York: St. Martin's Griffin, 2010), 129.

${ }^{17}$ Romney, 129.

${ }^{18}$ Paul Krugman, "Romney isn't concerned," New York Times, February 2, 2012. http://www.nytimes.com/2012/02/03/opinion/krugmanromney-isnt-concerned.html accessed May 30, 2012.
}

social safety nets (which he believes are adequate), but denies that there is any fundamental concern about the justice of market capitalism itself.

Two examples from Romney's campaign website illustrate his approach. Though Romney concedes that the early union movement established protections and benefits for workers, he maintains that unions now drive up costs, and that the federal government in particular is too favorable to unions. He proposes changes to rules governing union elections and the make-up of the NLRB, and supports establishing right-to-work laws and a prohibition on the use of union dues for political purposes. Absent from Romney's account is the understanding that unions and ownership check and balance one another. With respect to regulation, Romney criticizes the Obama administration - and in fact almost all previous administrations - for imposing layers of burdensome regulations and empowering federal bureaucrats to make regulations without presidential oversight. He argues that economic growth should be the key goal in any new regulatory structure, and proposes that the current directive to conduct cost-benefit analyses of proposed regulations should be replaced by attention to the costs only, and that future regulations must add a "zero dollars" cost to the economy. ${ }^{19}$ In both examples, he rejects entirely the Niebuhrian understanding of the dangers of the concentration of economic power, and succumbs to the impulse to make government work for business. As Niebuhr foresaw, "economic power does try to bend government to its own ends.",20

\section{Sins of the Social Utopian}

The Democratic Party, and the Obama campaigns especially, have worked to reclaim a Christian approach to politics for the Democratic left. During the 2008 campaign each of the major candidates in the Democratic Party made outreach to Christian voters an important part of its election effort (something that could not be said of John Kerry's 2004 campaign). ${ }^{21}$ Stephen Mansfield argues that Obama made "a conscious attempt to reclaim the religious voice of the American political left." 22

As an example of the way that President Obama has tried to explain his economic policies in Christian terms we can

\footnotetext{
$\overline{19} \mathrm{http}: / /$ www.mittromney.com/jobs (Accessed May 30, 2012).

${ }^{20}$ Irony, 93, 99, 100.

${ }^{21}$ Frank Lambert, Religion in American Politics: A Short History (Princeton: Princeton University Press, 2008), 221, 226, 242-246; Amy Sullivan, The Party Faithful: How and Why Democrats are Closing the God Gap (New York: Scribner, 2008), 205-208, 213218; E. J. Dionne, Souled Out: Reclaiming Faith and Politics after the Religious Right (Princeton: Princeton University Press, 2009), 194-195.

${ }^{22}$ Mansfield, xv, xxii.
} 
consider an early speech he made about the stimulus package. In April 2009 Obama described the work of his first hundred days in office in a speech called "The New Foundation." At the center of that speech Obama explained that the United States "must lay a new foundation for growth and prosperity." In Obama's words, "We must build our house upon a rock." ${ }^{23}$ Obama drew the image explicitly from the Sermon on the Mount (a fact little noticed by political scientists and commentators). That is, at the center of Obama's account of his economic stimulus is a biblical teaching - a biblical foundation to his administration's economic "New Foundation." The foundation of Obama's economic program includes a concern for the salvation of the community that is exemplified in the Social Gospel tradition. ${ }^{24}$

In his New Foundation speech Obama suggests that social salvation is possible. Obama joins this gospel foundation to social science utopianism. The Obama administration's economic policy is grounded in an elevation of the social sciences, including behavioral economics, in the policy-making process. Early in his term the president asked for a report to "clarify the role of the behavioral sciences in formulating policy." 25 Obama directed the OIRA to examine ways to incorporate the social and behavioral sciences into the formulation of administration policy. ${ }^{26}$ The belief in the unlimited potential of the social sciences to provide rational direction to the lives of the community is, in Niebuhr's account, a product of an especially modern sin that grows from the desire to conquer nature. It is a modern version of the impossible dream of the rule of reason. ${ }^{27}$

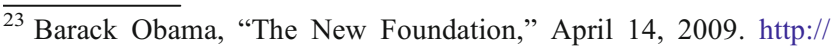
www.whitehouse.gov/the-press-office/remarks-president-economygeorgetown-university (accessed July 31, 2011)

${ }^{24}$ In his interview with David Brooks Obama offered a precis of Niebuhr's Irony of American History. In his 2011 Prayer Breakfast speech Obama gave a summation of important aspects of Niebuhr's Nature and Destiny of Man. Largely missing from Obama's reading is one lesson of Moral Man and Immoral Society, in which Niebuhr broke with important aspects of the social gospel movement.

${ }^{25}$ Justin Vaughn and Jose D. Villalobos, "The Obama Administration's Challenges After the 'War on Science': Reforming Staffing Practices and Protecting Scientific Integrity in the Executive Branch." Review of Policy Research 26, no. 6 (2009): 803-19.

${ }^{26}$ Indeed, Harvey Mansfield and Andrew Ferguson point to Obama's embrace of the social sciences, and especially behavioral economics, as "the governing theory" of his policies. Ferguson, "Nudge Nudge, Wink Wink," Weekly Standard, April 19, 2010; Mansfield, "What Obama Isn't Saying," Weekly Standard, February 8, 2010; Michael Grunwald, "How Obama is Using the Science of Change," Time, April 2, 2009; John B. Judis, "The Quiet Revolution," The New Republic, February 1, 2010; Peter Berkowitz, "Obama and the State of Progressivism, 2011," Policy Review (December 2010 and January 2011); George Packer, "The New Liberalism." The New Yorker November 17, 2008; and Robert Westbrook, "The Liberal Agony." The Christian Century September 20, 2011.

${ }^{27}$ Reinhold Niebuhr, The Nature and Destiny of Man: A Christian Interpretation. v. 1 (Louisville: Westminster John Knox Press, 1996), vol.1, 122; Irony, 67, 85-86.
}

The administration's tendency in this direction can be seen in the president's idealization of the Affordable Health Care Act, his policies in green energy, and the extravagance of his claims for the Buffett Rule. In his remarks about the health care legislation, Obama said that "America's workers and America's families and America's small businesses deserve the security of knowing that here, in this country, neither illness nor accident should endanger the dreams they've worked a lifetime to achieve." ${ }^{28}$ The legislation depends on the creation of an intricate economic system that accomplishes a public good by promoting the profits of a private industry, ignoring the very different goals of the two. Obama's rhetoric belied the realism any statesman must achieve and the humility any Christian must maintain. Obama has pursued a variety of administrative methods to accomplishing his environmental goals - including both market-based and command-and-control regulations - with decidedly mixed results. The American Recovery and Reinvestment Act included 4.5 billion dollars for green construction in federal buildings, a program designed to advance the green construction industry through economies of scale rather than direct subsidies. With regard to fuelefficiency, Obama brokered a deal for new CAFÉ regulations to require 54.5 miles per gallon average by 2025 (almost doubling the current standard). Unfairly or not, the signature program of Obama green policy is the failed loan to the Solyndra company (a program begun during the Bush administration). Underlying these programs is an unrealistic and even utopian presumption of the harmony of social goods. As Obama's campaign website declares, "we never have to choose between protecting our environment and strengthening our economy." 29 Finally, in response to the yawning budget deficit, Obama has proposed the Buffett Rule, aimed at increasing the tax share on millionaires and billionaires. ${ }^{30}$ But this proposal has hardly won universal praise from analysts. The decline of manufactures and the rising unequal distribution of wealth in America reflect a global trend reaching back decades, and such systemic problems cannot be resolved by tweaking the tax code. ${ }^{31}$

\footnotetext{
${ }^{28}$ Barack Obama, transcript provided by White House. New York Times, "Obama's Remarks on House Health Bill Passage," 22 March $2010 \mathrm{http} / /$ www.nytimes.com/2010/03/22/health/policy/22text-obama.html?pagewanted=all Accessed 30 May 2012.

${ }^{29} \mathrm{http}: / /$ www.barackobama.com/record/environment? source=issuesnav (accessed June 1, 2012)

${ }^{30} \mathrm{http}$ //www.barackobama.com/record/taxes? source=primary-nav Accessed 31 May 3012

${ }^{31}$ Even liberal economists who laud the Buffet rule believe it is far too small to fix the nation's budget problems, or ameliorate the inequality of the distribution of wealth. Annie Lowrey, "For Two Economists, the Buffett Rule is Just a Start," New York Times, April 16, 2012, http:/ www.nytimes.com/2012/04/17/business/for-economists-saez-andpiketty-the-buffett-rule-is-just-a-start.html?pagewanted=all Accessed 31 May 2012.
} 


\section{The Christian Prophet and the Political Economy}

Niebuhr argued that there is "pretty conclusive evidence that an uncontrolled economy does not automatically make for justice, and that a compounding of political and economic power, according to collectivist programs, will threaten both justice and liberty. ${ }^{, 32}$ While Niebuhr held that the Christian approach to economic justice demands an "inclination to seek the neighbor's good and a contrite awareness that we are not inclined to do this," he also reminds us that "there is no one in society good or wise enough to finally to determine how the individual's capacities had best be used." ${ }^{, 33}$ It is a large part of the purpose of government to regulate behavior, and to balance competing economic interests, but Niebuhr also warns that "bureaucratic decisions" can make "too narrow" our realm of "unregulated choices.",34

While Niebuhr insists on recognition of our own sins and uncertainties (and therefore insists as well on toleration of diverse perspectives), he also demands that we assert our own conception of the right. Thus Christians are called to struggle politically to promote biblical economic justice, that can never be finally realized. Analyzing laissez-faire economics to realize that it cannot achieve a biblical economic justice is vital, but must be balanced by a caution against social utopian confidence in achieving a final solution to the issues of economic fairness. While engaged with the world, the prophetic Christian rejects any partisan claim to bring heaven to earth, but seeks to bring as much Christian good as humanly possible to this fallen realm.

The 2012 presidential election offers the public a choice between two children of light, one who believes that a free market is productive of social harmony (and turns a blind eye to questions of social justice that emerge), another who believes that progressive government can resolve our political differences (and tends to downplay the tensions among interests and goods). In contrast, Niebuhr counseled that no final answer to our social problems was possible. In 2013 we may hope that one of these children of light will confront reality, and will adopt a political program that is less ideological. But America's culture of optimism - and our short collective memory - may not welcome such realism.

R. Ward Holder is Professor of Theology at Saint Anselm College.

Peter B. Josephson is Associate Professor of Politics at Saint Anselm College.

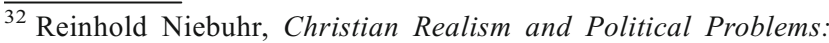
Essays on Political, Social, Ethical, and Theological Themes (New York: Charles Scribner's Sons, 1953), 88-91.

${ }^{33}$ Reinhold Niebuhr, "Christian Faith and the Economic Life of Liberal Society", in Goals of Economic Life, ed. A. Dudley Ward (New York: Harper and Brothers, 1953), 448; Irony, 93-99, 104; Moral, 266. Like Aristotle Niebuhr teaches that no partisan ideology ever represents the whole truth or the entirety of right. "There is an element of truth in each position which becomes falsehood, precisely when it is carried through too consistently." In the Politics Aristotle writes that "all fasten on a certain sort of justice, but proceed only to a certain point, and do not speak of the whole of justice in its authoritative sense." The reason is that "most people are bad judges concerning their own things." Aristotle emphasizes that the confusion arises over faulty understandings of equality and inequality (Book III, chapter 9, 1280a915; III.12.1282b16-23). See also Federalist 10, in which Madison finds that the cause of faction is "sown in the nature of man, and in religious and political zealotry and ambition". Madison adds that "the most common and durable source of factions, has been the various and unequal distribution of property." Compare Aristotle, Politics, V.2-3. In Volume II of The Nature and Destiny of Man Niebuhr points in particular to the party that asserts "the absolute validity" of the principle of equality, on the one hand, and the party that asserts "the impossibility of achieving it," on the other; 255 .

${ }^{34}$ Irony, 93, 100.
} 